\title{
Geochemical and isotopic evolution of groundwater in the Wadi Watir watershed, Sinai Peninsula, Egypt
}

\author{
Mustafa A. Eissa • James M. Thomas $\cdot$ Ronald L. Hershey • \\ Maher I. Dawoud • Greg Pohll - Kamal A. Dahab • \\ Mohamed A. Gomaa $\cdot$ Ashraf R. Shabana
}

Received: 8 May 2012/ Accepted: 31 May 2013/Published online: 25 June 2013

(C) The Author(s) 2013. This article is published with open access at Springerlink.com

\begin{abstract}
The Wadi Watir delta in the Wadi Watir watershed is a tourist area in the arid southeastern part of the Sinai Peninsula, Egypt, where development and growth of the community on the delta are constrained by the amount of groundwater that can be withdrawn sustainably. To effectively manage groundwater resources in the Wadi Watir delta, the origin of groundwater recharge, groundwater age, and changes in groundwater chemistry in the watershed needs to be understood. Mineral identification, rock chemistry, water chemistry, and the isotopes of hydrogen, oxygen, and carbon in groundwater were used to identify the sources, mixing, and ages of groundwater in the watershed and the chemical evolution of groundwater as it flows from the upland areas in the watershed to the developed areas at the Wadi Watir delta. Groundwater in the Wadi Watir watershed is primarily from recent recharge while groundwater salinity is controlled by mixing of chemically different waters and dissolution of minerals and salts in the aquifers. The El Shiekh Attia and Wadi El Ain areas in the upper Wadi Watir watershed have different recharge sources, either from recharge from other areas or from different storm events. The downgradient Main Channel area receives groundwater flow primarily
\end{abstract}

M. A. Eissa $(\bowtie) \cdot$ M. A. Gomaa · A. R. Shabana

Division of Water Resource, Desert Research Center,

Matariya, Cairo, Egypt

e-mail: mustafa.eissa@dri.edu

M. A. Eissa · J. M. Thomas · R. L. Hershey · G. Pohll Division of Hydrologic Sciences, Desert Research Institute, Reno, NV, USA

M. I. Dawoud · K. A. Dahab Geology Department, Faculty of Science, Menoufiya University, Menoufiya, Egypt from the El Shiekh Attia area. Groundwater in the Main Channel area is the primary source of groundwater supplying the aquifers of the Wadi Watir delta.

Keywords Hydrochemical modeling - Isotopes · Groundwater recharge - Wadi Watir - Sinai Peninsula . Egypt

\section{Introduction}

In the past decade, rapid development in the Wadi Watir delta, in the Wadi Watir watershed, Gulf of Aqaba, Sinai Peninsula, Egypt (Fig. 1), primarily related to tourism, has resulted in increased demand on groundwater resources. Groundwater is being developed for various needs in coastal and arid areas of the Sinai where there are no other sources of fresh water. Groundwater beneath the Wadi Watir delta is the main source of potable water for this area. Groundwater occurs as a thin lens of fresh water and is very sensitive to pumping induced stresses. Thus, groundwater withdrawals have to be carefully managed to avoid deterioration of this valuable resource by upwelling of underlying saline groundwater and intrusion of seawater along the coast. To understand historic and current groundwater conditions in this area, and to predict future changes in groundwater availability and salinity, water chemistry and isotopic data are currently being used to: (1) identify mixing of different waters; (2) characterize the evolution of groundwater chemistry along flow paths; (3) determine the age of the groundwater; and (4) constrain a groundwater flow and solute transport model. The chemical and isotopic methods used in this study to delineate groundwater resources in the Sinai Peninsula area of Egypt are applicable to other similar hydrogeological settings throughout the world in arid to semi-arid environments. This 
study combines mineral identification, rock chemistry, water chemistry, and isotopic signatures of groundwater to determine the physical and geochemical processes that produce the observed water chemistry, which because of salinity increases limits the amount of potable groundwater that is available for use in the Wadi Watir delta.

\section{Background}

Study area

The Wadi Watir watershed is located in the southeastern part of the Sinai Peninsula, Egypt (Fig. 1). The watershed
Fig. 1 Location of groundwater samples in the Wadi Watir watershed

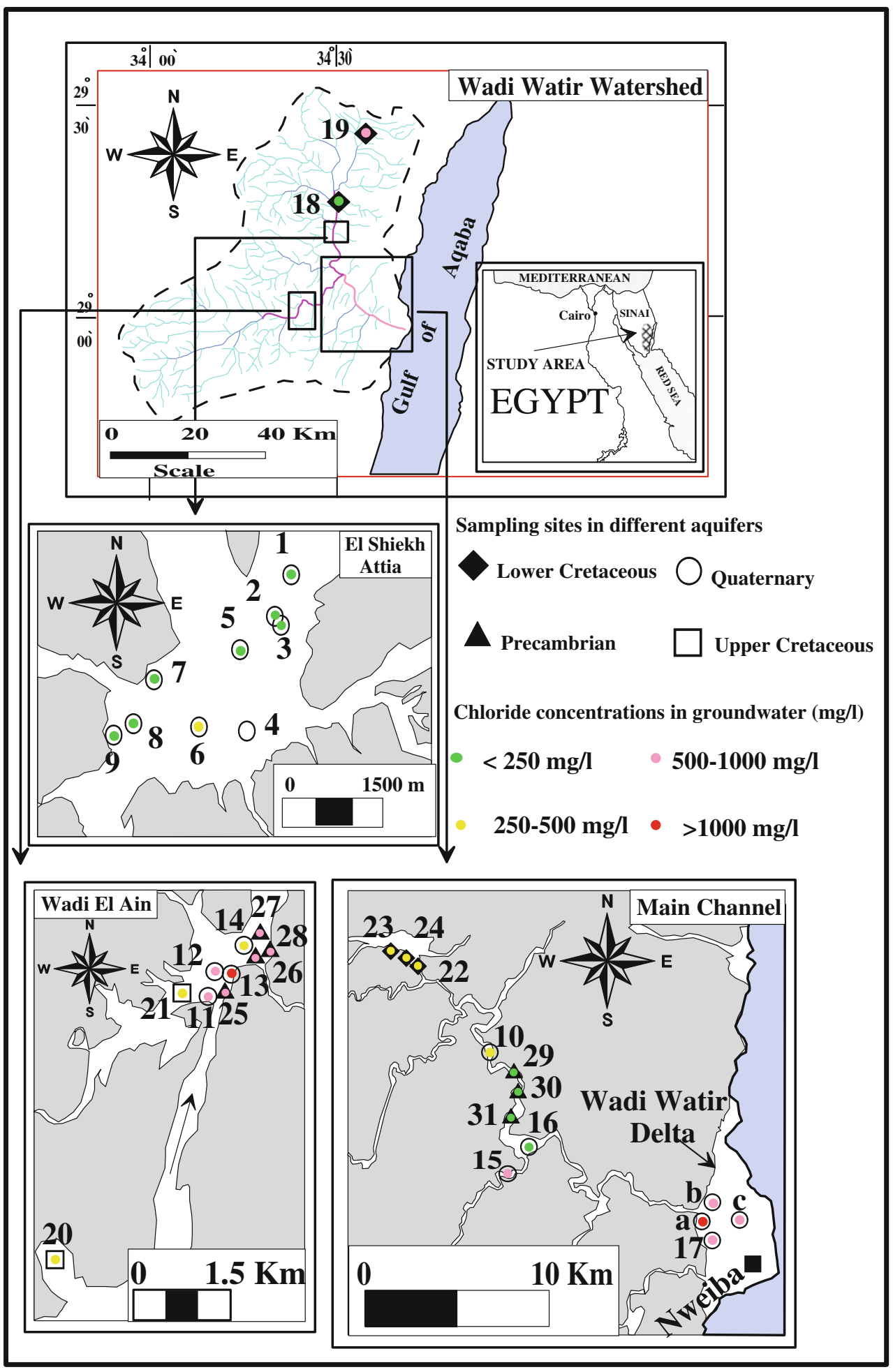


drains east toward the Gulf of Aqaba and is considered to be the most important wadi in this area because the city of Nuweiba, a tourist destination, and Nuweiba Harbor are located on the Wadi Watir delta. Nuweiba Harbor links Egypt with Saudi Arabia and Jordan.

\section{Geology}

The Wadi Watir watershed is underlain by rocks ranging in age from Precambrian to Quaternary (Figs. 2, 3). The Precambrian basement rocks are mainly composed of metamorphic and igneous rocks, including gneisses, metagabbro, metasediments, older gabbros and younger granites that are cut by basic dykes, joints, fractures and fault zones (EGSMA 1981). Cambrian rocks include the Araba and Naqous Formations (Hassan 1967; Said 1971). The Araba Formation (early Cambrian) is formed mainly of thick bedded, grayish and reddish, fine to mediumgrained ferruginous sandstone. The Naqous Formation (late Cambrian) is composed mainly of fluvial deposits of friable, white to light gray, fine grained, and pebbly quartz with authigenic clay minerals (Issawi and Jux 1982; Shabana 1998; Abdel-Rahman 2002). The Naqous
Formation unconformably overlies the Araba Formation and is overlain by the Malha Formation (Abdel-Rahman 2002). Cretaceous rocks are also present throughout the Wadi Watir watershed. They consist of three formations: the Malha Formation (early Cretaceous), which represent a clastic facies deposit of continental fluviatile environment of white sandstone locally conglomerated (El Beialy et al. 2010; CONOCO 1987), and the Wata and Raha Formations (late Cretaceous). The Wata Formation consists mainly of alternative beds of limestone and marl at the base; clay marl sandstone and bands of limestone in the middle; and dolomitic limestone and limestone at the top. The Raha Formation is primarily composed of fossiliferous alternating beds of limestone, shale, and sandy limestone at the base; shale and marl in the middle; and marly limestone and dolomite at the top (Shabana 1998). These two formations were deposited in shallow to deep marine open to restricted environments (Gertsch et al. 2008). The Quaternary deposits consist of erosional products of different sedimentary and rocks (El-Shazly et al. 1974; Eyal et al. 1980) and they are composed mainly of fine-to-course sands, gravels, and boulders of carbonate and rocks embedded in a silty and clayey matrix (El Kiki et al. 1992).

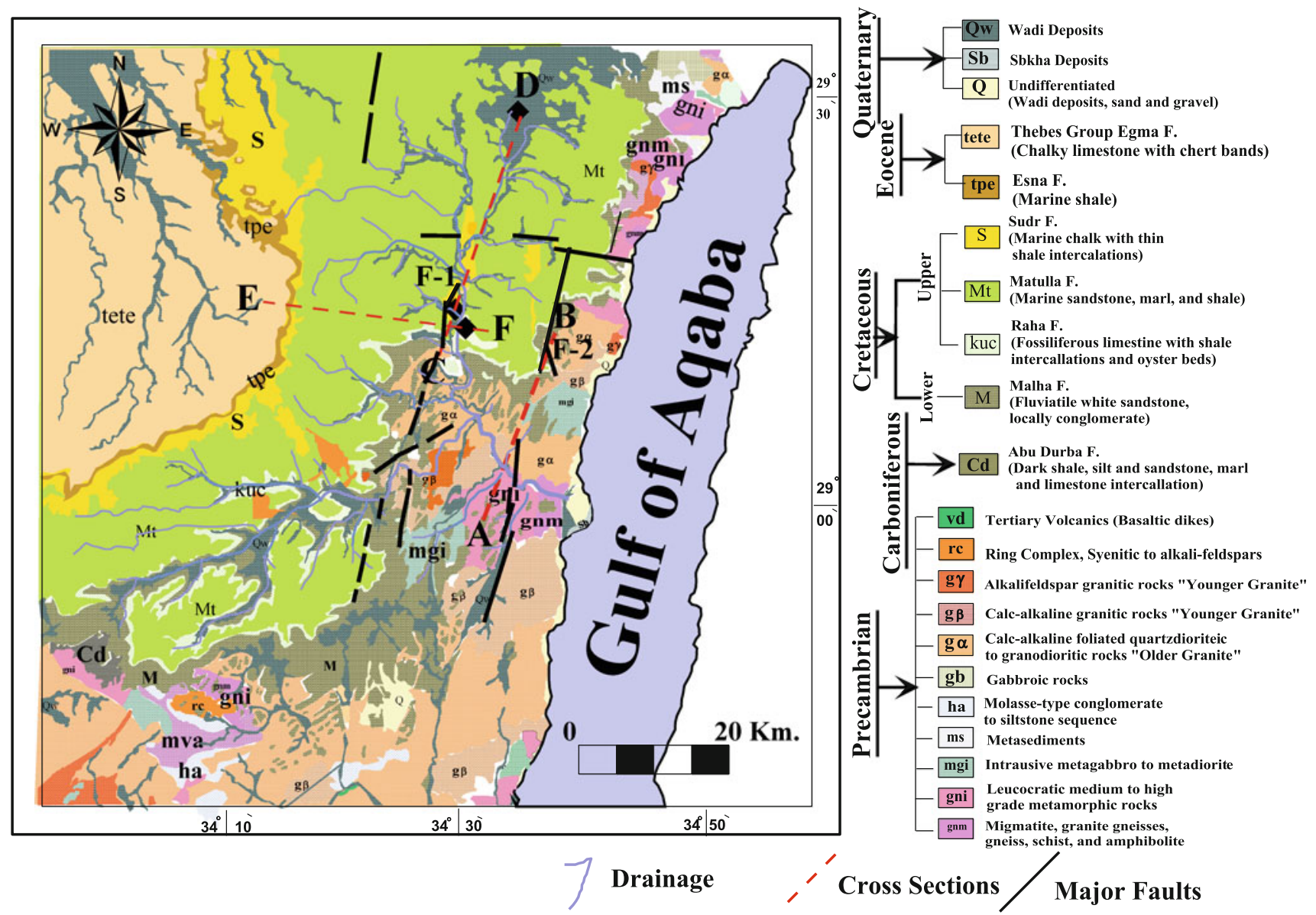

Fig. 2 Geological map of the study [modified from CONOCO (1987)] 


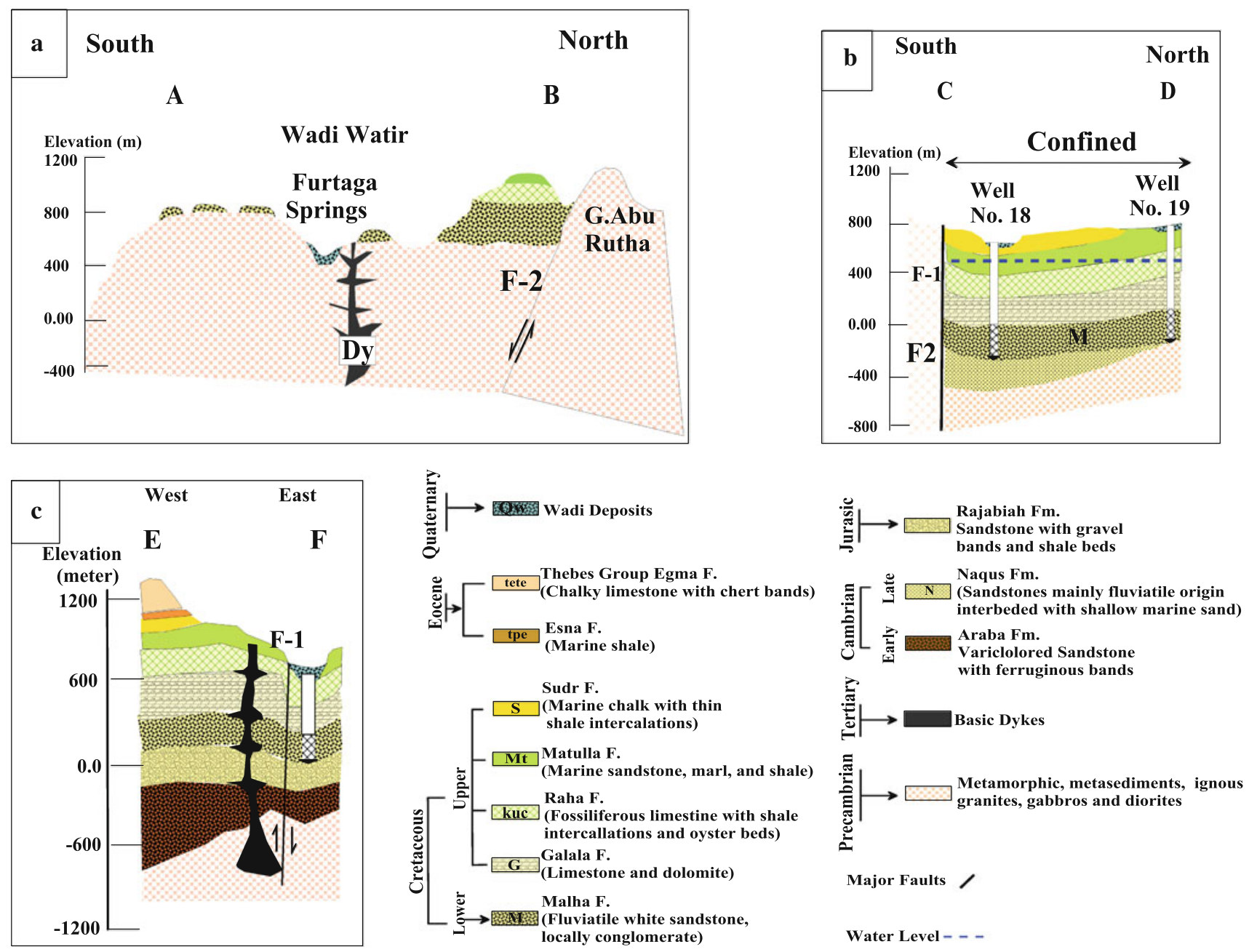

Fig. 3 Hydrogeological cross section $A-B, C-D$ and $E-F$. Locations of these cross sections are shown in Fig. 2. Cross sections are modified from Yehia (1998)

In Fig. 2, there are two sets of faults that trend northwest-southeast and north-south. Beadnell (1927) and Said (1962) studied these two sets in the El Shiekh Attia area and concluded that the northwest-southeast faults are older than the north-south trending faults.

\section{Methods}

Field and laboratory methods

Water samples were collected in March 2007. Thirty-four samples were collected from 25 hand-dug wells, four drilled wells, and three springs. Water samples were filtered in the field using a $0.45-\mu \mathrm{m}$ cellulose acetate filter; samples for major-ion and isotopic analysis were collected in 1-L polyethylene bottles. Depth to water, total depth, $\mathrm{pH}$ and electrical conductivity (EC) were measured in the field at the sampling location. Electrical conductivity was measured with an YSI model 35 conductivity meter. The
pH was measured with a WTW model LF 538 pH meter. The EC and pH meters were calibrated once daily. Majorion water chemistry analyses were conducted at the Egyptian Desert Research Center Water Central Laboratory using the methods of Rainwater and Thatcher (1960) and Fishman and Friedman (1985). Calcium and magnesium were determined by titration using $\mathrm{Na}_{2}$ EDTA. Sodium and potassium were determined by flame photometry using a standard curve. Carbonate and bicarbonate were determined by titration using sulfuric acid. Sulfate was determined by spectrophotometry. Chloride was determined by volumetric titration using silver nitrate. Silica, as $\mathrm{SiO}_{2}$, was determined by colorimetry using molybdate $\left[\left(\mathrm{NH}_{4}\right)_{6} \mathrm{Mo}_{7} \mathrm{O}_{24} \cdot 4 \mathrm{H}_{2} \mathrm{O}\right]$.

For quality assurance/quality control, each sample was analyzed in duplicate, and if the difference between the sum of cations and anions is more than $5 \%$, the sample analysis was repeated until an acceptable percent difference was obtained. For flame photometry and the spectrophotometry analysis, a set of standard solutions were 
measured for every set of ten samples. If the standard was not verified, then the standards were measured again until verification was met and the samples were re-analyzed.

Stable isotopic analyses were conducted at the University of Nevada, Reno. Stable isotopic analyses were performed using a Micromass Iso Prime stable isotope ratio mass spectrometer. $\delta^{2} \mathrm{H}$ analyses were performed using the method of Morrison et al. (2001). $\delta^{2} \mathrm{H}$ results are reported in units of \% VSMOW with an uncertainty of $\pm 1 \%$ (1 standard deviation). $\delta^{18} \mathrm{O}$ analyses were performed using the $\mathrm{CO}_{2}-\mathrm{H}_{2} \mathrm{O}$ equilibration method (Epstein and Mayeda 1953). $\delta^{18} \mathrm{O}$ results are reported in units of \%o VSMOW with an uncertainty of $\pm 0.2 \%$ ( 1 standard deviation). Carbon-14 analyses were conducted at the University of Arizona, Accelerator Mass Spectrometry Laboratory and results are reported as percent modern carbon (pmc) with an uncertainty of \pm 0.4 pmc. Mineralogy was identified by examination of rock thin sections using a polarizing light microscope. Rock chemical composition was determined by X-ray fluorescence at the University of Nevada, Reno.

Ground-surface elevations were surveyed for seven wells in the El Shiekh Attia area and three wells in the delta area using a global positioning system (GPS) LEICA TCRA1103 PLUS ROBOTIC 3 instrument with a laser reflector total station. These ground-surface elevations were used with depth to water measurements to draw water-level contours and determine groundwater flow direction in the El Shiekh Attia area (Fig. 4). The digital elevation model (DEM) map of Shuttle Radar Topographic Mission (STRM-90) was used to determine the groundsurface elevation for other wells and springs since GPS surveys were not conducted in these areas. These data, along with depth to water measurements, were used to determine the general direction of groundwater flow in the main channel aquifers. Because there is a large absolute

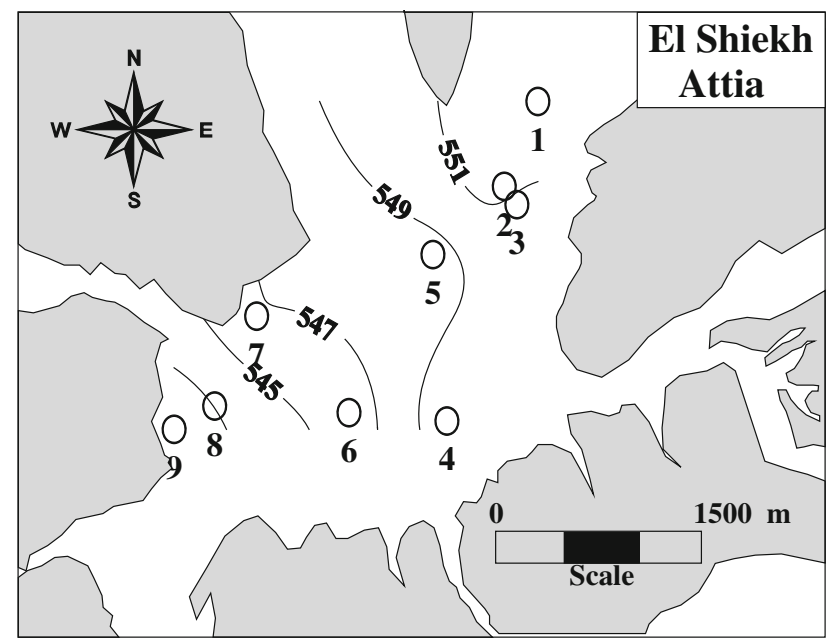

Fig. 4 Water level contours (meters) in the El Shiekh Attia area average vertical elevation error $(16 \mathrm{~m})$ for the DEM data (Gorokhovich and Voustianiouk 2006), water-level measurement points close to each other and having similar water-level elevations less than the DEM elevation error were assigned an average water-level elevation.

\section{Water-rock reaction modeling}

Inverse geochemical modeling (Plummer 1992) has been widely used in interpreting geochemical processes that account for the hydrochemical and isotopic changes in groundwater. The inverse geochemical model NETPATH 2.0 (Plummer et al. 1994) was used because of its ability to compute the mixing proportions of two to five waters and the net geochemical reactions that account for the observed chemical composition changes in groundwater along a flow path. The geochemical reactions and physical processes that produced the observed water chemistry were evaluated and several possible models are presented that identify water-rock interactions, mixing, and evaporation. Inverse geochemical modeling does not produce unique results, but this type of modeling does produce results that account for the changes in observed water chemistry along a flow path for phases (minerals, salts, or gases) that are known to occur in the aquifers and that are constrained by mineral and gas saturation data. A mineral or gas can only enter the water if the water is under saturated with respect to the mineral or gas, and it can only leave the water (precipitate from, or degas) if the water is super saturated with respect to the mineral or gas.

First, potential groundwater flow paths were identified using water-level information, $\delta^{2} \mathrm{H}$ and $\delta^{18} \mathrm{O}$ data, and major-ion chemistry. To determine water-rock interactions that are producing the observed water chemistry, the mineral phases of the aquifers were identified. Mineral phases were obtained from analysis of 12 rock samples from aquifers in the study area (Tables 1,2). Granitic rocks form the back bone of the mountain block recharge area and are the main source of Quaternary alluvial deposits in the study area.

The water-rock reaction models developed for this study were constrained by the major-ion concentrations of the groundwater and the mineral phases in the aquifers of the study area (Tables 3, 4). Halite was included as a phase in NETPATH models because of its occurrence in carbonate rocks of marine origin (Raha and Wata Formations) and because it is embedded in terrestrial sediments. Calcite and dolomite were included as phases in the model because of the presence of carbonate rocks in the study area. Clay sheets are present in the sediments so the clay minerals montmorillonite and illite were also included in the model. X-ray fluorescence results for granitic samples are presented in Table 2. These data were used to determine the average chemical 
Table 1 Results of petrographic analyses of rock samples

\begin{tabular}{|c|c|c|c|c|c|c|}
\hline \multirow[t]{2}{*}{ No } & \multirow[t]{2}{*}{ Area } & \multicolumn{2}{|c|}{ Mineral composition } & \multirow[t]{2}{*}{ Alterations } & \multirow[t]{2}{*}{ Texture } & \multirow[t]{2}{*}{ Rock type } \\
\hline & & Major & $\begin{array}{l}\text { Minor and } \\
\text { accessories }\end{array}$ & & & \\
\hline 1 & Main Channel & Plag, ortho, qz & $\begin{array}{l}\text { Biot, mica } \\
\text { magnetite, chlr }\end{array}$ & Argillaceous granite & $\begin{array}{l}\text { Medium-grained } \\
\text { plutonic rocks }\end{array}$ & Granite \\
\hline 2 & Main Channel & Plag, qz & Chlr, silica & $\begin{array}{l}\text { Strongly argillized plag } \\
\text { with more chlr and iron } \\
\text { oxides, red stained }\end{array}$ & $\begin{array}{l}\text { Very fine grained, } \\
\text { hypabysal }\end{array}$ & Basalt \\
\hline 3 & Main Channel & Plag, qz, ortho & Biot & $\begin{array}{l}\text { Intensively argillized felds, } \\
\text { biot altered to iron oxides } \\
\text { show hematization }\end{array}$ & $\begin{array}{l}\text { Medium to coarse } \\
\text { grained perthitic } \\
\text { texture }\end{array}$ & Granite \\
\hline 4 & Main Channel & Plag, ortho & Biot, apatite & $\begin{array}{l}\text { Argillized granite with } \\
\text { hematization }\end{array}$ & & Granite \\
\hline 5 & Main Channel & Plag & $\begin{array}{l}\text { Pyrox, augite, oliv, } \\
\text { serp }\end{array}$ & $\begin{array}{l}\text { Argillized iron oxides and } \\
\text { pyrox replaced by serp, } \\
\text { chlr and serp strongly iron } \\
\text { stained }\end{array}$ & & Olivine basalt \\
\hline 6 & Main Channel & Pyrox, plag & $\begin{array}{l}\text { Iron oxides, oliv, } \\
\text { magnetite, ilmenite }\end{array}$ & & Medium grained & Gabbros \\
\hline 7 & Main Channel & Plag, qz, ortho & $\begin{array}{l}\text { Biot, muscovite, } \\
\text { zircon }\end{array}$ & Less argillized felds & Medium grained & Biotite granite \\
\hline 8 & Wadi El Ain & Ortho, plag, qz & Biot & $\begin{array}{l}\text { Ortho is strongly } \\
\text { weathered, plag with } \\
\text { oxidized biot }\end{array}$ & & Biotite granite \\
\hline 9 & Wadi El Ain & Plag, pyrox, qz & Chlr, magnetite, clay & $\begin{array}{l}\text { Plag replaced by clay and } \\
\text { pyrox by chlr }\end{array}$ & $\begin{array}{l}\text { Medium to coarse } \\
\text { grained }\end{array}$ & Gabbros \\
\hline 10 & Wadi El Ain & Plag, pyrox & $\begin{array}{l}\text { Clay minerals, chlr, } \\
\text { zircon, opaques }\end{array}$ & $\begin{array}{l}\text { Pyrox altered to chlr and } \\
\text { plag to clay }\end{array}$ & $\begin{array}{l}\text { Medium to coarse } \\
\text { grained }\end{array}$ & Gabbros \\
\hline 11 & Wadi El Ain & $\begin{array}{l}\text { Qz, ortho, plag, } \\
\text { felds }\end{array}$ & Opaques & $\begin{array}{l}\text { Weak to moderate } \\
\text { argillization }\end{array}$ & $\begin{array}{l}\text { Coarse grained } \\
\text { graphic texture }\end{array}$ & Granite \\
\hline 12 & Wadi El Ain & Plag, ortho, qz & $\begin{array}{l}\text { No opaques no } \\
\text { apatite no zircon }\end{array}$ & $\begin{array}{l}\text { Oxidation of biot with iron } \\
\text { stained }\end{array}$ & $\begin{array}{l}\text { Medium grained } \\
\text { texture }\end{array}$ & Granite \\
\hline
\end{tabular}

Plag plagioclase, ortho orthoclase, felds feldspars, qz quartz, biot biotite, chlr chlorite, serp serpentine, pyrox pyroxene, oliv olivine

Table 2 Results of X-ray fluorescence of granite samples

\begin{tabular}{llllllllllllll}
\hline Rock type & Basin & $\mathrm{No}$ & $\mathrm{SiO}_{2}$ & $\mathrm{TiO}_{2}$ & $\mathrm{Al}_{2} \mathrm{O}_{3}$ & $\mathrm{Fe}_{2} \mathrm{O}_{3}$ & $\mathrm{MnO}$ & $\mathrm{MgO}$ & $\mathrm{CaO}$ & $\mathrm{Na}_{2} \mathrm{O}$ & $\mathrm{K}_{2} \mathrm{O}$ & $\mathrm{P}_{2} \mathrm{O}_{5}$ & $\mathrm{Loss}_{\text {on ignition }}$ \\
\hline Granite & Main Channel & 1 & 73.41 & 0.15 & 15.91 & 1.11 & 0.04 & 0.02 & 1.28 & 3.53 & 3.65 & 0.06 & 0.83 \\
Granite & Main Channel & 2 & 75.03 & 0.16 & 14.23 & 1.77 & 0.03 & 0.00 & 0.63 & 3.04 & 4.70 & 0.01 & 0.41 \\
Granite & Main Channel & 3 & 74.77 & 0.14 & 13.90 & 1.63 & 0.04 & 0.01 & 1.02 & 2.81 & 4.66 & 0.02 & 1.00 \\
Granite & Main Channel & 4 & 74.26 & 0.16 & 14.94 & 1.38 & 0.04 & 0.26 & 1.39 & 2.95 & 3.92 & 0.05 & 0.65 \\
Granite & Wadi El Ain & 5 & 77.85 & 0.08 & 12.67 & 1.30 & 0.01 & 0.04 & 0.20 & 1.98 & 5.13 & 0.02 & 0.72 \\
Granite & Wadi El Ain & 6 & 78.73 & 0.08 & 12.12 & 1.23 & 0.02 & 0.00 & 0.45 & 2.26 & 4.67 & 0.00 & 0.43 \\
Granite & Wadi El Ain & 7 & 76.48 & 0.08 & 12.32 & 1.15 & 0.02 & 0.00 & 0.49 & 2.28 & 4.69 & 0.01 & 2.48 \\
\hline
\end{tabular}

composition for a composite granite for the NETPATH models that represents felsic igneous rocks found throughout the study area $\left(\mathrm{Ca}_{0.33} \mathrm{Mg}_{0.01} \mathrm{Na}_{1.02} \mathrm{~K}_{1.72} \mathrm{Si}_{21} \mathrm{Al}_{3.74} \mathrm{Fe}_{0.74}\right)$.

Samples with major-ion analysis electroneutrality error of greater than $5 \%$ were not used in water-rock reaction models. Major-ion analyses were not corrected to $0 \%$ electroneutrality so any electroneutrality error was carried through each model.
An acceptance criterion for a valid water-rock reaction model was the precipitation or dissolution of no more than $10 \mathrm{mmol} / \mathrm{L}$ of a phase, unless one of the major ions making up the phase in question had a dissolved concentration greater than $10 \mathrm{mmol} / \mathrm{L}$ in the initial and final waters. In this case, more than $10 \mathrm{mmol} / \mathrm{L}$ of a phase could precipitate or dissolve, but the amount of the phase precipitating or dissolving could not be greater than twice the dissolved 
Table 3 Constraints, phases, and parameters used in NETPATH models

\begin{tabular}{llc}
\hline Constraints & Phases & Parameters \\
\hline $\begin{array}{c}\text { Calcium, carbon, magnesium, } \\
\text { potassium, sodium, sulfur }\end{array}$ & $\begin{array}{c}\text { Calcite, composite granite }\left(\mathrm{Ca}_{0.33} \mathrm{Mg}_{0.01} \mathrm{Na}_{1.02} \mathrm{~K}_{1.72} \mathrm{Si}_{21} \mathrm{Al}_{3.7} 4 \mathrm{Fe}_{0.74}\right) \text {, dolomite, cation } \\
\text { exchange, gypsum, halite, illite, mafic montmorillonite, Na-montmorillonite, }\end{array}$ & $\begin{array}{c}\text { Evaporation, } \\
\text { silica } \\
\text { mixing, carbon } \\
\text { isotopic exchange }\end{array}$ \\
\hline
\end{tabular}

concentration of the major ion making up the phase in question.

\section{Results and discussion}

\section{Groundwater flow system}

The study area contains four main water bearing formations that are recharged by flash floods when the area receives heavy winter storms (October-April) and by infiltration of precipitation on the mountain block (Research Institute for Water Research 1989; Himida 1997; Japan International Cooperation Agency 1999). For the Wadi Watir basin catchment area, the average annual rainfall between 1998 and 2007 was $192.7 \times 10^{6} \mathrm{~m}^{3} /$ year (Milewski et al. 2009). This is close to the average annual value of $164.9 \times 10^{6} \mathrm{~m}^{3} /$ year estimated by Masoud (2009) between 1960 and 1990. Sultan et al. (2011) estimated the total average annual recharge for the Nubian Sandstone in the Wadi Watir watershed is $1.83 \times 10^{6} \mathrm{~m}^{3} /$ year for 1998-2007. A detailed groundwater flow model was developed and calibrated for the Wadi Watir watershed using average annual recharge estimates and groundwater discharge measured for the well field and Furtaga Springs in the main channel. This modeling effort produced a water balance based on estimated groundwater recharge, measured groundwater discharge, and model calibration based on water levels with an average annual recharge value of $1.58 \times 10^{6} \mathrm{~m}^{3} /$ year, for 1982-2009 (Eissa et al. 2013). Elewa and Qaddah (2011) ranked the Nubian Sandstone aquifer (lower Cretaceous) in eastern Sinai and the Furtaga Springs area in Wadi Watir as promising areas with very high annual groundwater recharge. Wadi Watir is composed of many aquifers ranging from land surface to a depth that exceeds $700 \mathrm{~m}$ from the ground surface (Fig. 3a-c). These aquifers include the Quaternary alluvial aquifer, the upper Cretaceous (Wata and Raha Formations) carbonate aquifer, the lower Cretaceous sandstone aquifer (Malha Formation), and the Precambrian granitic aquifer. The Quaternary, upper Cretaceous, and Precambrian aquifers are generally unconfined, water-table aquifers, while the lower Cretaceous is a confined aquifer. The Precambrian aquifer underlies most of the study area (Fig. 3a-c). The Quaternary aquifer is present in the eastern Wadi Watir alluvial fan, the main channel of Wadi Watir, the Wadi El Ain area, and in the El Shiekh Attia area (Figs. 1, 5). Water-level contours in the Quaternary alluvial aquifer of the El Shiekh Attia area show that groundwater flows from northeast to the southwest, generally following the surface-water drainage (Fig. 4). The average groundwater elevation for wells tapping the Quaternary aquifer in the El Shiekh Attia and Wadi El Ain areas is 559 and $641 \mathrm{~m}$, respectively; further downstream in the alluvial aquifer, the water level is $237 \mathrm{~m}$ at site 16 and $0.9 \mathrm{~m}$ (average) in the delta at sites 17, a, and b (Fig. 5; Table 4). These data indicate that groundwater in the Quaternary alluvial aquifer flows downgradient in the drainages to the delta.

The groundwater in Wadi El Ain occurs in three different aquifers, the Quaternary, the upper Cretaceous, and the Precambrian. Water-level elevations are highest in the upper Cretaceous at sites $20(688 \mathrm{~m})$ and $21(660 \mathrm{~m})$ (Figs. 1, 5; Table 4). Water-levels are lower in the Precambrian (643 m, average of sites 25 and 27) and in the Quaternary alluvial aquifer (641 m, average of sites 13 and 14) (Figs. 1, 5; Table 4).

The lower Cretaceous aquifer occurs locally in the upper reach of the Main Channel (sites 22, 23, and 24; Fig. 1) and extends northward in the central Sinai Peninsula (Fig. 5). Water in the confined, lower Cretaceous aquifer (Yehia 1998) flows northward from sites 22, 23, and 24 (average water-level elevation $469 \mathrm{~m})$ toward sites $18(430 \mathrm{~m})$ and 19 (419 m) (Fig. 5).

The Precambrian aquifer outcrops in the mountains and underlies most of the study area (Figs. 3, 5). This aquifer outcrops at Wadi El Ain (sites 25, 26, 27, and 28; Fig. 1) and in the Main Channel at Furtaga Springs (sites 29, 30, 31; Fig. 1; Table 4). The average water-level elevation for wells tapping the Precambrian aquifer at Wadi El Ain is $643 \mathrm{~m}$ (sites 25 and 27) while it is much lower in the Main Channel at an average of $347 \mathrm{~m}$ at Furtaga Springs (sites 29-31) (Fig. 5). At Furtaga Springs, low permeability dykes create barriers to groundwater flow in this area of the Main Channel (Fig. 3a).

The general flow direction of groundwater, which occurs under unconfined conditions in the Quaternary, upper Cretaceous and Precambrian aquifers, is mainly from the upper watershed areas of Wadi El Ain and El Shiekh Attia downgradient through the Main Channel toward the Wadi 


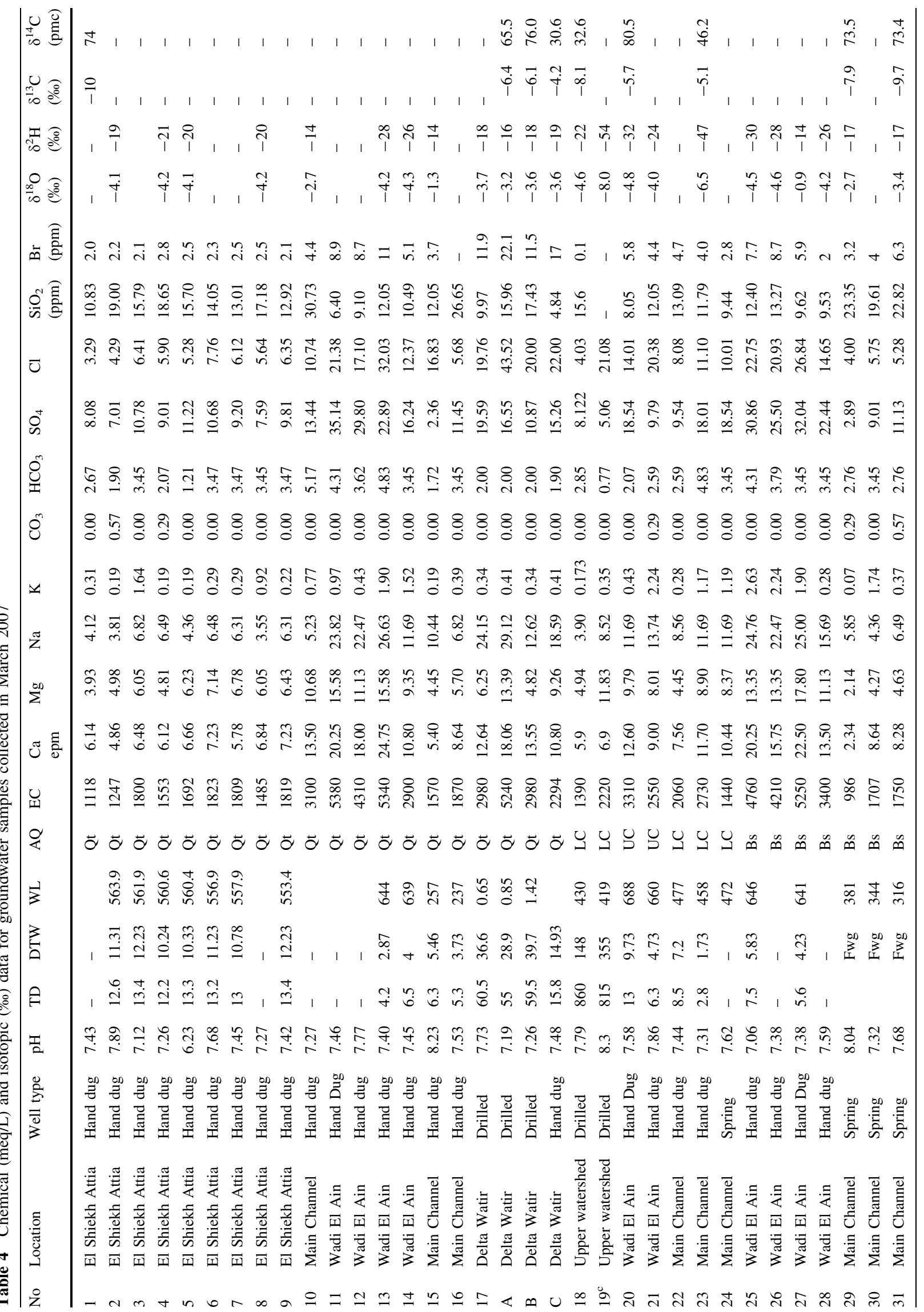


Watir delta. The main groundwater withdrawals are from the Wadi Watir delta area, located downgradient of the upper Wadi Watir watershed. In the upgradient parts of the Wadi Watir watershed, groundwater withdrawals are restricted to one drilled well (site 18) with a submersible pump and a few $\mathrm{m}^{3} /$ day from each hand-dug well.

Environmental isotopes

Hydrogen $\left(\delta^{2} \mathrm{H}\right)$ and oxygen $\left(\delta^{18} \mathrm{O}\right)$ isotopic ratios of water are ideal tracers that can be used to determine the source(s) and mixing of groundwater because they are part of the water molecule, are not involved in geochemical reactions, and are sensitive to physical processes such as groundwater mixing and evaporation (Dansgaard 1964; Clark and Fritz 1997). In the study area, the isotopic composition of groundwater varies according to the location and the source(s) of groundwater recharge. The stable isotope ratios of hydrogen and oxygen of groundwater, along with water chemistry data, are shown in Table 4.

Groundwater from the Quaternary alluvial aquifer in the El Shiekh Attia area (Figs. 1, 6) close to the Global Meteoric Water Line (GMWL) (Craig 1961), has isotopic signatures similar to the weighted mean value of local precipitation in the Sinai (Abd El Samei and Sadek 2001; Abd El-Samei 1995), is similar to the amount-weighted isotopic mean of precipitation from the Rafah and El Arish weather stations (IAEA and WISER 2008), and is low in chloride (Fig. 7). These data indicate that the main source of groundwater in the Quaternary alluvial aquifer in the El Shiekh Attia area is recent precipitation.

The isotopic signatures of groundwater in the Quaternary alluvial aquifer, upper Cretaceous carbonate aquifer, and Precambrian granitic aquifer in the Wadi El Ain area (Figs. 1, 6) are isotopically depleted relative to weighted mean value of local precipitation in the Sinai (Abd El Samei and Sadek 2001; Abd El-Samei 1995) and groundwater from the El Shiekh Attia area, and have much higher chloride (Figs. 1,7). These data suggest that groundwater in Wadi El Ain is derived from a source different than recent precipitation and different than groundwater from the Quaternary alluvial aquifer of the El Shiekh Attia area. Groundwater in the Wadi El Ain area may have been recharged during a past cooler climate, recharged from another area not considered in this study, or possibly recharged from localized storm events that were isotopically depleted relative to weighted mean value of local precipitation in the Sinai (Abd El Samei and Sadek 2001; Abd El-Samei 1995).

Groundwater in the lower Cretaceous aquifer flows northward from the Main Channel are; site 19 in the very northern part of the Wadi Watir watershed is the isotopically lightest groundwater found in the watershed (Figs. 1,6) and 


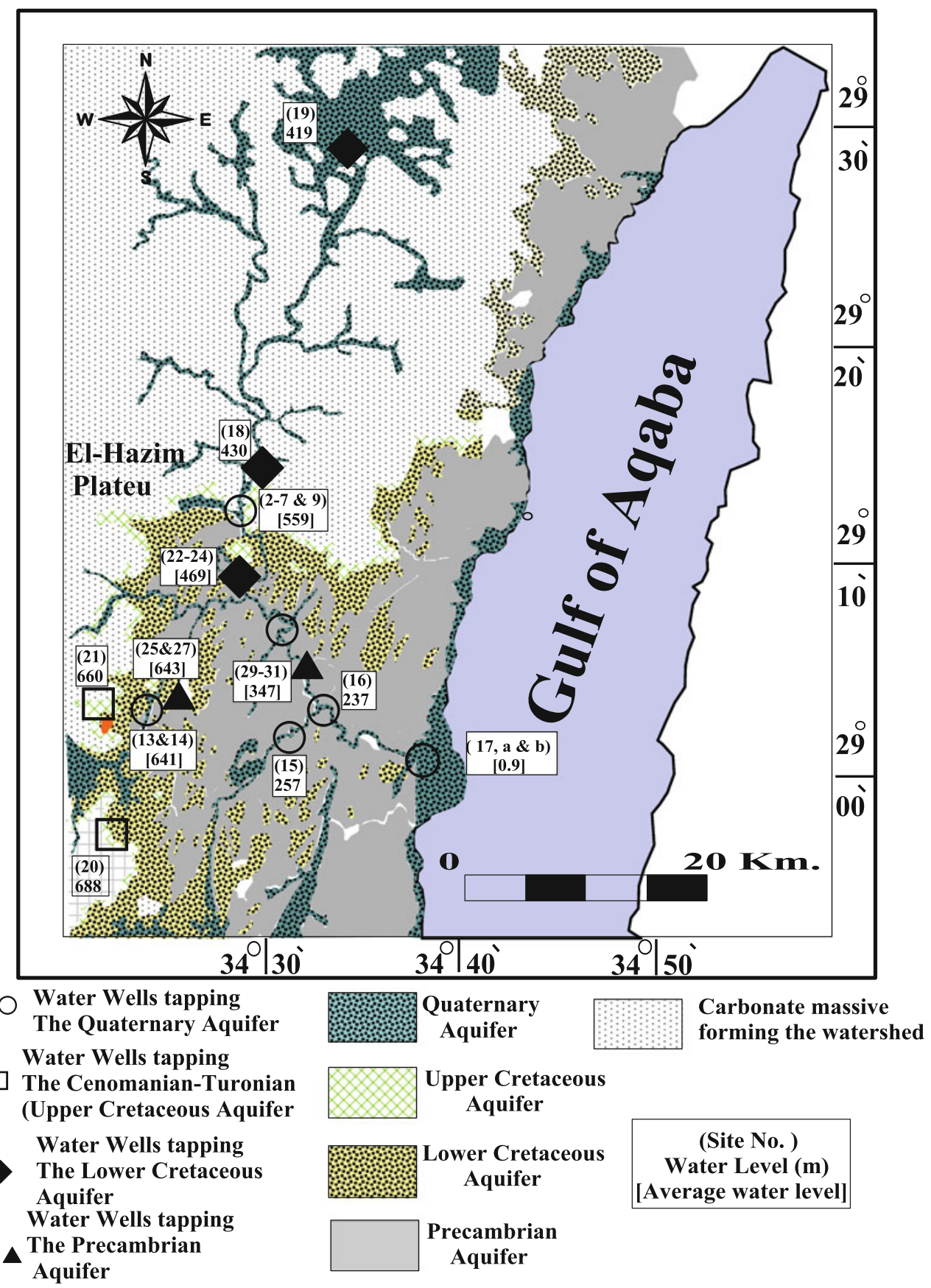

Fig. 5 Hydrogeological map of the study area

has considerable chloride (Figs. 1, 7). Site 18, which is located between sites 22, 23, and 24 in the Main Channel area and site 19 (Fig. 1), is isotopically very similar to recent precipitation and groundwater in the alluvial aquifer in $\mathrm{El}$ Shiekh Attia, and has low chloride. Groundwater in the lower Cretaceous aquifer in the Main Channel area at site 23 appears to be a mixture of recent precipitation and isotopically light groundwater from the lower Cretaceous aquifer similar to that found at site 19; site 23 also lies close to a mixing line between recent precipitation and site 19 in
Fig. 6. Similarly, site 23 lies near a mixing line between recent precipitation (and site 8) and site 19 in Fig. 7 comparing isotopic signatures and chloride concentrations. These interpretations are consistent with those found by Yehia (1998) and Abd El Samei and Sadek (2001).

Isotopic data for groundwater in the Precambrian aquifer in the Main Channel area (sites 29 and 31; Figs. 1, 6) fall on an evaporation line originating from Quaternary alluvial aquifer groundwater in the El Shiekh Attia area. These data suggest that groundwater in the Precambrian aquifer in the 
Table 5 NETPATH modeling results $(\mathrm{mmol} / \mathrm{L})$ for the Wadi Watir watershed

\begin{tabular}{|c|c|c|c|c|c|c|c|c|c|c|c|c|c|c|c|c|}
\hline \multirow[t]{2}{*}{ Basin } & \multirow{2}{*}{$\begin{array}{l}\text { Initial } \\
\text { (site 1) } \\
\text { Numbers }\end{array}$} & \multirow{2}{*}{$\begin{array}{l}\text { Initial } \\
\text { (site 2) } \\
\text { in Fig. } 1\end{array}$} & \multirow[t]{2}{*}{$\begin{array}{l}\text { Final } \\
\text { water }\end{array}$} & \multicolumn{2}{|c|}{$\begin{array}{l}\text { Mixing } \\
\text { percent }\end{array}$} & \multicolumn{10}{|c|}{ Phases precipitated or dissolved } & \multirow{2}{*}{$\begin{array}{l}\text { The } \\
\text { calculated } \\
\text { mixing } \\
\text { percent of } \\
\text { site } 1 \\
\text { (using } \delta^{2} \mathrm{H} \\
\text { isotopes) } \\
(\%)\end{array}$} \\
\hline & & & & $\begin{array}{l}\text { Site } \\
1 \\
(\%)\end{array}$ & $\begin{array}{l}\text { Site } \\
2 \\
(\%)\end{array}$ & Cal & Gyp & Dol & Ilt & $\begin{array}{l}\text { Mont- } \\
\text { Maf }\end{array}$ & $\begin{array}{l}\text { Na- } \\
\text { Mont }\end{array}$ & Gr & Biot & Hal & Ex & \\
\hline \multirow{2}{*}{$\begin{array}{l}\text { El Shiekh } \\
\text { Attia }\end{array}$} & 2 & - & 4 & - & - & -0.39 & 1.00 & 0.38 & - & -0.59 & - & 0.02 & - & 1.61 & 0.52 & - \\
\hline & 2 & - & 9 & - & - & -1.93 & 1.40 & 1.88 & -0.92 & -2.34 & - & 0.43 & - & 2.06 & - & - \\
\hline \multirow{2}{*}{$\begin{array}{c}\text { Wadi El } \\
\text { Ain }\end{array}$} & 20 & - & 25 & - & - & -5.50 & 6.19 & 4.24 & - & -4.80 & - & 1.47 & - & 8.78 & 1.43 & - \\
\hline & 20 & Rainwater & 14 & 66 & 34 & -3.37 & 1.92 & 2.81 & - & -3.60 & - & 0.86 & - & 2.99 & - & 60 \\
\hline \multirow{5}{*}{$\begin{array}{l}\text { Main } \\
\text { Channel }\end{array}$} & 23 & Rainwater & 18 & 15 & 85 & -2.35 & 2.72 & 2.23 & - & - & -6.6 & - & - & 2.38 & 0.98 & 16 \\
\hline & 2 & - & 31 & - & - & -0.39 & 2.06 & 0.67 & - & -1.43 & - & 0.16 & - & 0.99 & 0.76 & \\
\hline & 31 & - & 17 & - & - & -0.81 & 4.25 & - & -2.68 & -1.24 & - & - & 1.67 & 14.5 & 1.60 & \\
\hline & 2 & - & 17 & - & - & -1.64 & 6.31 & 0.88 & -0.50 & - & - & - & 0.45 & 15.5 & 2.46 & \\
\hline & 2 & Rainwater & 17 & 48 & 52 & -4.16 & 8.14 & 2.66 & - & - & - & 0.14 & - & 17.7 & 2.25 & 47 \\
\hline
\end{tabular}

Positive values mean the phase is going into solution while negative values mean the phase is being removed from the solution

Cal calcite, Gyp gypsum, Dol dolomite, Ilt illite, Mont-Maf mafic montmorillonite, Na-Mont sodium montmorillonite, Gr composite granite, Biot biotite, Hal halite, Ex cation exchange, - no data

Main Channel area is derived from either the upgradient El Shiekh Attia area or local recharge from recent precipitation. Note that the chloride concentrations in sites 29 and 31 have not increased because of evaporation and are similar to chloride concentrations in El Shiekh Attia (Figs. 1, 7). Chloride data suggest that local recharge of recent precipitation may be the more likely source of water at sites 29 and 31 .

Two groundwater samples in the study area, sites 15 and 27, have undergone substantial evaporation and lie along an evaporation line from groundwater in the Wadi El Ain area (Fig. 6). Site 27 is located within the Wadi El Ain area in the Precambrian aquifer (Fig. 1). Site 15 is located on a tributary to the Main Channel (Fig. 1) in the Quaternary alluvial aquifer; although site 15 has a similar evaporated isotopic signature to that of site 27 , it is geographically (and hydrologically) unrelated to groundwater in the Wadi El Ain area. Using the average $\delta^{18} \mathrm{O}$ value for un-evaporated groundwater from the Wadi El Ain area (Fig. 6; Table 4; average of sites 13, 14, 20, 21, 25, 26, and 28) and the Rayleigh equation (Clark and Fritz 1997), an evaporation factor for site 27 is 1.2 .

Wells 17, a, b, and c are located in the Quaternary alluvial aquifer in the Wadi Watir delta, downgradient from the Main Channel area (Fig. 1). Groundwater from these wells lies on an evaporation line originating from the upgradient El Shiekh Attia area (Fig. 6). Isotopic data suggest that groundwater in the Quaternary alluvial aquifer originates from either the El Shiekh Attia area or local recharge of recent precipitation. Chloride concentrations in the Wadi Watir delta are much higher than in the El Shiekh Attia area or upgradient groundwater in the Main Channel area (Figs. 1, 7). Groundwater in the delta is likely influenced by an underlying saline groundwater reported by El Refaei (1992), El Kiki et al. (1992) and El Sayed (2006) that may be upwelling because of increased groundwater pumping.

\section{Water-rock reaction models using NETPATH}

In the El Shiekh Attia area, groundwater in the Quaternary alluvial aquifer flows downgradient from northeast to southwest, increases in dissolved solids (Table 4), and then flows toward the Main Channel area. Groundwater in this area is not evaporated (Figs. 6, 7). Geochemical modeling results suggest that gypsum, dolomite, halite, and granite dissolve as groundwater flows downgradient (e.g. site 2 to site 4 or site 9) while calcite and clays are precipitated and some cation exchange occurs (Table 5). Calculated mineral saturation indices (SI) are consistent with changes in mineral phases in NETPATH models (Table 6).

In the Wadi El Ain area, groundwater occurs in three different aquifers, yet all are similar isotopically indicating that all are derived from the same source. Upgradient groundwater (site 20) in the upper Cretaceous aquifer flows downgradient to the Precambrian (e.g. sites 25 and 27) and Quaternary (e.g. site 14) aquifers. Water-rock reaction models for flow from the upper Cretaceous to the Precambrian suggest that gypsum, dolomite, granite, and halite dissolve while calcite and clays are formed with some 
cation exchange (Table 5). Models suggest that Quaternary alluvial aquifer groundwater is a mixture of upper Cretaceous (66\%) groundwater and recent precipitation (34\%) with dissolution of gypsum, dolomite, granite, and halite while calcite and clays are formed (Table 5). Petrographic analyses of rocks from the Wadi El Ain area (Table 1) are consistent with the modeled dissolution of igneous rocks and formation of clays. Calculated mineral SIs are consistent with dissolution and precipitation of mineral phases in NETPATH models (Table 6) including de-dolomitization driving the dissolution of dolomite despite over-saturated SIs (Back et al. 1983).

Water-rock reaction modeling of groundwater flow in the lower Cretaceous aquifer suggests that groundwater at site 18 is a mixture of upgradient groundwater from site 23
(15\%) and recent precipitation (85\%). Models suggest dissolution of gypsum, dolomite, and halite while calcite and clays are formed with some cation exchange (Table 6).

Groundwater in the Precambrian aquifer in the central Main Channel area emanates from Furtaga springs (sites 29, 30, 31; Figs. 1, 5). Water-rock reaction models of this groundwater can be made by simply reacting El Shiekh Attia area groundwater with minerals. These models suggest dissolution of gypsum, dolomite, composite granite, and halite while calcite and clays are formed with some cation exchange (Table 6).

From the Main Channel, groundwater flows downgradient into the Wadi Watir delta (e.g. site 17). Water-rock reaction models of groundwater in the Quaternary alluvial aquifer in the delta can be made by with upgradient
Fig. 6 Relationship between $\delta^{18} \mathrm{O}$ and $\delta^{2} \mathrm{H}$ for groundwater in the El Shiekh Attia, Wadi El Ain, and the Main Channel areas. The samples outside of the El Shiekh Attia samples, shown as overlapping circles, and the Wadi El Ain samples within the ellipse are the Main Channel area samples

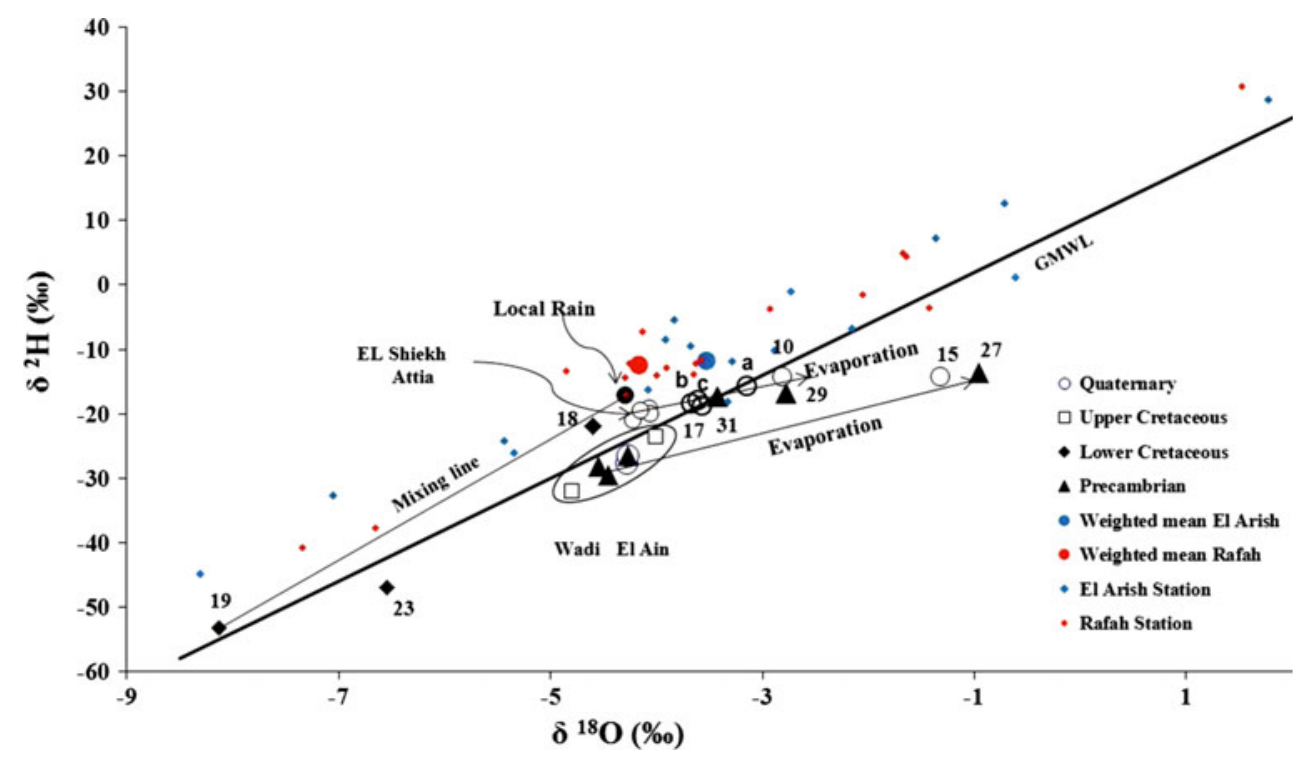

Fig. 7 Relationship between $\delta^{18} \mathrm{O}$ and $\mathrm{Cl}$ for groundwater in the El Shiekh Attia, Wadi El Ain, and the Main Channel areas. The samples outside of the El Shiekh Attia samples, shown as overlapping circles, and the Wadi El Ain samples within the circle are the Main Channel area samples

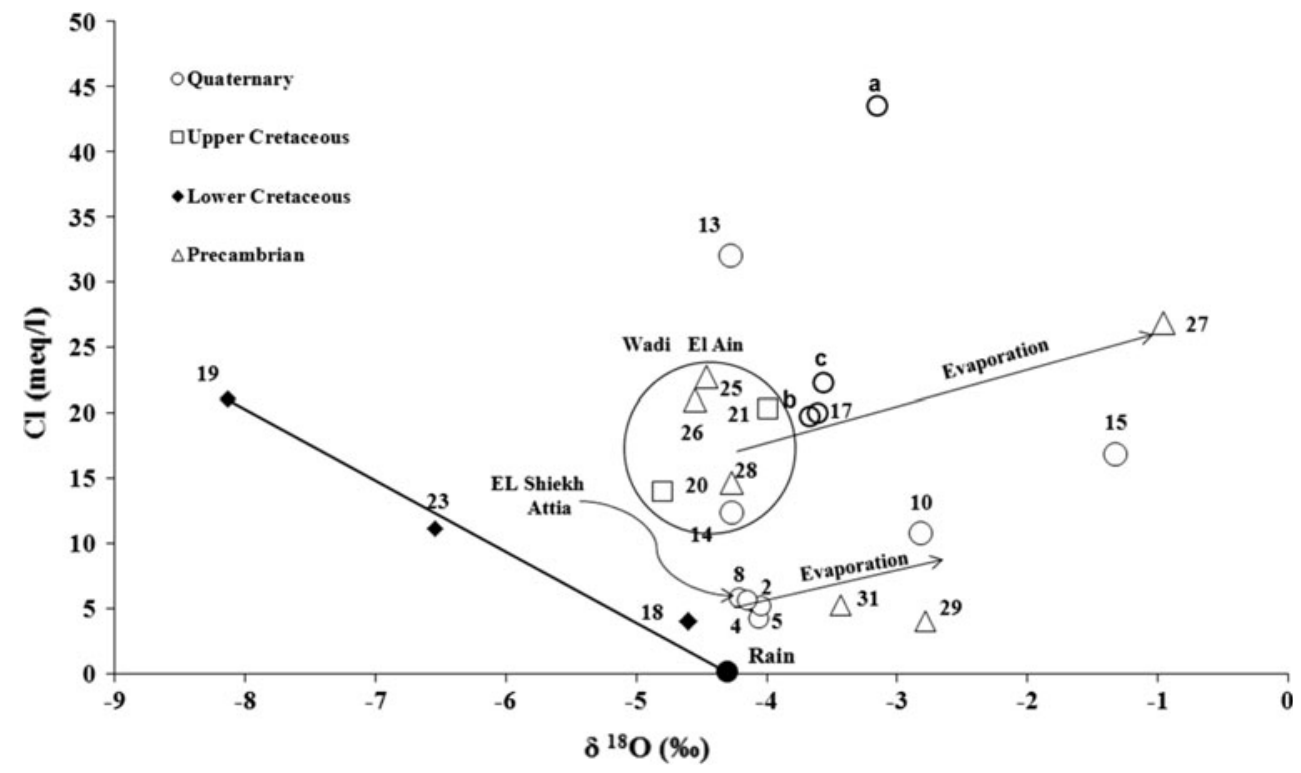


groundwater from the Precambrian aquifer at Furtaga Springs (e.g. site 31) dissolving gypsum, biotite, and halite while precipitating calcite and clays with cation exchange (Table 6). Wadi Watir delta groundwater can also be derived from upgradient Quaternary alluvial aquifer water (e.g. site 2) by dissolving gypsum, dolomite, biotite, and halite while precipitating calcite and clays with cation exchange. Successful water-rock reaction models could also be produced that had upgradient alluvial aquifer water (48\% site 2) mixing with recent precipitation (52\%) to produce Wadi Watir delta groundwater by dissolving gypsum, dolomite, granite, and halite while precipitating calcite and with cation exchange. Mixing percentages estimated by the water-rock reaction model (NETPATH) are close to the estimated percentages using deuterium isotopes (Table 5).

\section{Groundwater ages}

Carbon-13 $\left(\delta^{13} \mathrm{C}\right)$ and carbon-14 $\left({ }^{14} \mathrm{C}\right)$ were analyzed in groundwater samples from one well in the El Shiekh Attia area (site 1); three wells (sites 18, 20, and 23) and two springs (sites 29 and 31) in the Main Channel area; and three wells (site a, b and c) in the Wadi Watir delta area (Table 4). Water-rock reaction models were developed to explain the changes in water chemistry along flow paths, including mixing of different waters (Table 5), and to correct groundwater ages as needed for interaction of groundwater carbon isotopes with aquifer materials. The carbon isotope age correction models adjusted groundwater ${ }^{14} \mathrm{C}$ activity for various geochemical reactions including inorganic carbon reactions in the soil zone, carbonate mineral dissolution, and isotopic exchange with carbonate minerals in the aquifer matrix. Carbon-14 ages were corrected using the Original Data Method in NETPATH; this method has been used to highlight the influence of isotopic exchange and carbonate dissolution through the flow path (Plummer et al. 1994).

The $\delta^{13} \mathrm{C}$ value and ${ }^{14} \mathrm{C}$ activity of $\mathrm{CaCO}_{3}$ in the aquifer matrix were assumed to be $0 \%$ and $0 \mathrm{pmc}$, respectively. When correcting groundwater ages, the ${ }^{14} \mathrm{C}$ activity of the initial water $\left(A_{0}\right)$ at, or near, the recharge area and the ${ }^{14} \mathrm{C}$ activity of groundwater along a flow path must be defined (Wigely and Muller 1981). The initial water may be a groundwater sample from upgradient, or an assumption that represents the water chemistry at the recharge area (Van der Kemp et al. 2000). For modeling, carbon isotopic data for site 1 in the El Shiekh Attia area were used as the initial water for estimating downgradient groundwater ages because: (1) it was the most upgradient water in the El Shiekh Attia area, which supplies most of the water to the downgradient Main Channel area; (2) it was the most dilute sample in the project area (expect for one spring); (3) it contained the most negative $\delta^{13} \mathrm{C}$ value indicative of recent recharge through the soil zone; and (4) it had a ${ }^{14} \mathrm{C}$ activity of $74 \mathrm{pmc}$, which combined with a $\delta^{13} \mathrm{C}$ value of $-10 \%$ indicates that this groundwater is modern in age $(<1,000$ years old $)$.

All model corrected ${ }^{14} \mathrm{C}$ groundwater ages were modern, except for groundwater at site 18 , which had a corrected ${ }^{14} \mathrm{C}$ of 4,600 years (Table 7 ). The drilled well at site 18 taps into the lower Cretaceous aquifer. Shiftan (1961) reported that the water in the Nubian Sandstone aquifer in the study area is of Pleistocene age. Issar and Michaeli (1972) used ${ }^{14} \mathrm{C}$ to date groundwater in this aquifer and reported ages between 13,000 and 30,000 years. Abd El Samei and Sadek (2001) estimated the age for groundwater at site 19 in the lower Cretaceous aquifer to be 22,000 years. The well at site 18 , although tapping the lower Cretaceous aquifer, is clearly a mixture of recent precipitation and older groundwater in the lower Cretaceous aquifer as indicated by isotopic data, chemistry data,

Table 6 Mineral saturation indices for phases in NETPATH geochemical models

\begin{tabular}{lrrrrrrrrrrr}
\hline Basin & No & Calcite & Gypsum & Dolomite & Illite & Ca-Mont & Albite & Anorth & Kspar & Chalcedy & Halite \\
\hline El Shiekh Attia & 2 & 0.23 & -1.13 & 0.50 & 0.88 & 1.12 & -1.32 & -3.58 & 0.03 & 0.11 & -4.59 \\
El Shiekh Attia & 4 & -0.29 & -0.96 & -0.65 & 1.56 & 2.32 & -1.13 & -3.56 & 0.01 & 0.13 & -4.22 \\
El Shiekh Attia & 9 & 0.14 & -0.90 & 0.27 & 0.89 & 1.44 & -1.62 & -3.81 & -0.42 & -0.03 & -4.20 \\
Wadi El Ain & 14 & 0.26 & -0.64 & 0.49 & 1.03 & 1.04 & -1.64 & -3.91 & 0.12 & -0.12 & -3.12 \\
Delta Watir & 17 & 0.33 & -0.54 & 0.39 & 0.17 & 0.41 & -1.39 & -3.92 & -0.60 & -0.14 & -3.69 \\
El Shiekh Attia & 18 & 0.65 & -1.04 & 1.44 & -2.23 & -2.09 & -2.95 & -4.33 & -1.90 & -0.21 & -4.18 \\
Wadi El Ain & 20 & 0.22 & -0.54 & 0.37 & 0.15 & 0.37 & -1.98 & -4.08 & -0.77 & -0.23 & -3.35 \\
Main Channel & 23 & 0.24 & -0.57 & 0.41 & 1.29 & 1.50 & -1.50 & -3.71 & 0.15 & -0.07 & -3.73 \\
Wadi El Ain & 25 & 0.13 & -0.27 & 0.12 & 1.82 & 2.04 & -1.14 & -3.66 & 0.53 & -0.04 & -3.05 \\
Main Channel & 31 & 0.35 & -0.78 & 0.48 & 1.54 & 1.84 & -0.86 & -3.27 & 0.55 & 0.22 & -4.27 \\
\hline
\end{tabular}

Positive values indicate oversaturation; negative values indicate undersaturation 
Table 7 Calculated groundwater ages using NETPATH

\begin{tabular}{|c|c|c|c|c|c|c|c|c|c|c|}
\hline \multirow[t]{2}{*}{ Basin } & \multicolumn{2}{|c|}{ Initial water } & \multirow[t]{2}{*}{ Final water } & \multirow{2}{*}{$\begin{array}{l}\text { Carbon isotopic } \\
\text { exchange }(\mathrm{mmol} / \mathrm{L})\end{array}$} & \multicolumn{2}{|l|}{$\delta^{13} \mathrm{C}$} & \multicolumn{2}{|l|}{${ }^{14} \mathrm{C}$} & \multirow[t]{2}{*}{$\mathrm{Ev}$} & \multirow{2}{*}{$\begin{array}{l}\text { Age } \\
\text { (years) }\end{array}$} \\
\hline & Site 1 & Site 2 & & & $\begin{array}{l}\text { Computed } \\
(\%)\end{array}$ & $\begin{array}{l}\text { Observed } \\
(\%)\end{array}$ & $\begin{array}{l}\text { Computed } \\
(\mathrm{pmc})\end{array}$ & $\begin{array}{l}\text { Observed } \\
(\mathrm{pmc})\end{array}$ & & \\
\hline Wadi El Ain & 1 & & 20 & 1.7 & -5.45 & -5.70 & 34.9 & 80.5 & & Modern \\
\hline \multirow[t]{4}{*}{ Main Channel } & 1 & 23 & 18 & 0.1 & -8.11 & -8.10 & 57.1 & 32.6 & - & 4,600 \\
\hline & 1 & & 29 & 0.1 & -7.48 & -7.90 & 53.7 & 73.5 & - & Modern \\
\hline & 1 & & 31 & 0.1 & -9.79 & -9.70 & 71.5 & 73.5 & 1.14 & Modern \\
\hline & 1 & $\mathrm{a}$ & $\mathrm{c}$ & 0.4 & -4.17 & -4.20 & 25.7 & 30.5 & - & Modern \\
\hline
\end{tabular}

Site 1 represents recent groundwater recharge

$E v$ evaporation factor

and water-rock reaction modeling. Sultan et al. (2011) reported that the Nubian sandstone aquifer in Sinai was primarily recharged by previous wet climates, and currently receives modern meteoric recharge under dry climatic conditions. Rosenthal et al. (2007) confirm that the lower Cretaceous aquifers in the central eastern Sinai, and at the Negev comprise paleo water mostly recharged and replenished during the Pleistocene age.

Groundwater in the Precambrian aquifer and downgradient in the Quaternary alluvial aquifer in the Main Channel and in the Wadi Watir delta are modern in age (Table 7) indicating that groundwater is from recent precipitation and not groundwater recharged under a different climatic regime.

\section{Summary and conclusions}

Groundwater in the El Shiekh Attia area has isotopic signatures that are similar to rain and show that the water has not been evaporated. Thus, these isotopic values indicate that recent precipitation is the main source of groundwater recharge to aquifers in this area. Groundwater in the Wadi El Ain area is isotopically depleted relative to groundwater in the El Shiekh Attia area and is isotopically similar to recent rain indicating that groundwater in aquifers in this area is derived from a source different from that of the El Shiekh Attia area. Groundwater in the Main Channel area is primarily derived from the upgradient El Shiekh Attia area and recent precipitation as indicated by isotopic and chemical data and water-rock reaction modeling. Groundwater chemistry evolves as groundwater flows from the upgradient El Shiekh Attia area through the Main Channel area to the Wadi Watir delta. Dissolution of gypsum, halite, and igneous rocks is the primary contributor to increase in major-ion concentrations while precipitation of calcite and formation of clays remove ions from the water.

Corrected ${ }^{14} \mathrm{C}$ groundwater ages are all modern except for one sample from the lower Cretaceous aquifer with a corrected age of 4,600 years. These groundwater ages have very important implications for groundwater management. Groundwater currently being pumped is being replenished by recent recharge and is not a paleo water from a different climatic regime. Thus, this resource can be managed in a sustainable way by not pumping more than that recharged on an average annual basis. If this groundwater resource was much older, it could only be managed as a one-time use and not as a sustainable resource.

Acknowledgments Acknowledgement goes to the Egyptian Cultural and Educational Bureau at Washington DC for funding this work and to Dr. Simon Poulson, Department of Geological Sciences and Engineering, University of Nevada, Reno, for conducting the stable isotopic analyses.

Open Access This article is distributed under the terms of the Creative Commons Attribution License which permits any use, distribution, and reproduction in any medium, provided the original author(s) and the source are credited.

\section{References}

Abd El Samei SG, Sadek MA (2001) Groundwater recharge and flow in the lower Cretaceous Nubian sandstone aquifer in the Sinai Peninsula, using isotopic techniques and hydrochemistry. Hydrogeol J 9:378-389

Abd El-Samei SG (1995) Isotopic and hydrochemical studies on the groundwater of Sinai Peninsula (Dissertation). Ain Shams University, Egypt

Abdel-Rahman IF (2002) Physical and chemical characteristics of silica sand deposits of Wadi Watir region, Sinai. Acta Miner Petrogr Szeged 43:79-83

Back W, Hanshaw BB, Plummer LN, Rahn PH, Rightmire CT, Rubin M (1983) Process and rate of dedolomitization-mass transfer and ${ }^{14} \mathrm{C}$ dating in a regional carbonate aquifer. Geol Soc $\mathrm{Am}$ Bull 94:1415-1429

Beadnell HJL (1927) The wilderness of Sinai. Arnold, London

Clark I, Fritz P (1997) Environmental isotopes in hydrogeology. Lewis, New York

CONOCO (1987) Geologic map of Egypt, scale 1:500000. Continental Oil Company, Egypt

Craig H (1961) Isotopic variations in meteoric waters. Science 133:1702-1703 
Dansgaard W (1964) Stable isotopes in precipitation. Tellus $16: 436-468$

EGSMA (1981) Geological map of Egypt. Scale 1:2000000

Eissa MA, Thomas JM, Pohll G, Hershey RL, Dahab KA, Dawoud MI, Gomaa MA, ElShiekh A (2013) Groundwater resource sustainability in the Wadi Watir delta, Gulf of Aqaba, Sinai, Egypt. Hydrogeol J (in press)

El Beialy YS, Head JM, El Atfy SH (2010) Palynology of the midCretaceous Malha and Galala formations, Gebel El Minshera, North Sinai, Egypt. PALAIOS 25:517-526. doi:10.2110/palo. 2009.p09-128r

El Kiki MF, Eweida EA, El Refeai AA (1992) Hydrogeology of the Aqaba rift border province. In: Proceeding of the 3rd Conference on Geology Sinai Development, Ismailia, Egypt, pp 91-100

El Refaei AA (1992) Water resources of southern Sinai, Egypt geomorphological and hydrogeological studies. Dissertation, Cairo University, Cairo

El Sayed MH (2006) Comparative study of water quality of the Quaternary aquifer in Wadi Watir basin and its delta, Southeast Sinai, Egypt. Egypt J Desert Res 56:17-46

Elewa H, Qaddah A (2011) Groundwater potentiality mapping in the Sinai Peninsula, Egypt, using remote sensing and GISwatershed-based modeling. Hydrogeol J 19:613-628. doi:10.1007/ s10040-011-0703-8

El-Shazly EM, Abddel-Hady MA, El-Ghawaby MA, El-Kassas IA, El-Shazly MM (1974) Geology of Sinai Peninsula from ERTS-1 satellite images. Acad Sci Res Tech Remote Sens Proj

Epstein S, Mayeda T (1953) Variation of ${ }^{18} \mathrm{O}$ content of waters from natural sources. Geochim Cosmochim Acta 4:213-224

Eyal M, Bartov Y, Shimron AE, Bentor YK (1980) Sinai geologic map, scale 1:500000. Ministry of energy and infrastructure, Research Earth Science Israel, Israel

Fishman MJ, Friedman LC (1985) Methods for determination of inorganic substances in water and fluvial sediments. US Geological Survey (book 5, chapter A1), open file report, p 85-495

Gertsch B, Keller G, Adatte T, Berner Z, Kassab AS, Tantawy AAA, El-Sabagh AM, Stueben D (2008) Cenomanian-Turonian transition in a shallow water sequence of the Sinai, Egypt. Int J Earth Sci. doi:10.1007/s00531-008-0374-4

Gorokhovich Y, Voustianiouk A (2006) Accuracy assessment of the processed SRTM-based elevation data by CGIAR using field data from USA and Thailand and its relation to the terrain characteristics. Remote Sens Environ 104:409-415

Hassan AA (1967) A new Carboniferous occurrence in the Abu Durba, Sinai, Egypt. In: 6th Arabian Petroleum Conference, Baghdad, vol 2

Himida IH (1997) Water resources of Wadi Watir. Internal report, Desert Research Center, Hydrology Department (in Arabic)

IAEA, WISER (2008) Water isotope system for data analysis, visualization, and electronic retrieval. WISER Version 0.7

Issar AAB, Michaeli A (1972) On the ancient water of the upper Nubian sandstone aquifer in Central Sinai and Southern Israel. J Hydrol 17
Issawi B, Jux U (1982) Contribution on the stratigraphy of the Paleozoic rocks in Egypt. Geol Surv Egypt 64:28

JICA (Japan International Cooperation Agency) (1999) South Sinai groundwater resources study in the Arab Republic of Egypt. Pacific Consultants International and Sanyu Consultants Inc, Tokyo (report)

Masoud AA (2009) Runoff modeling of the wadi systems for estimating flashflood and groundwater recharge potential in Southern Sinai, Egypt. Arab J Geosci. doi:10.1007/s12517-0090090-9

Milewski A, Sultan M, Yan E, Becker R, Abdeldayem A, Soliman F, Gelili K (2009) A remote sensing solution for estimating runoff recharge in arid environments. J Hydrol 373:1-14

Morrison J, Brockwell T, Merren T, Fourel F, Phillips AM (2001) Online high-precision stable hydrogen isotopic analyses on nanoliter water samples. Anal Chem 73:3570-3575

Plummer LN (1992) Geochemical modeling of water-rock interaction: past, present, future. In: Kharaka YK, Maest AS (eds) Water-rock interaction. Balkema, Rotterdam, pp 23-33

Plummer LN, Prestemon EC, Parkhurst DL (1994) An interactive code (NETPATH) for modeling net geochemical reactions along a flow path, version 2.0. US Geol Surv Water Resour Invest Rep 94-4169: 130

Rainwater FH, Thatcher LI (1960) Methods for collection and analysis of water samples. US Geol Surv Water Supply 1454

Research Institute for Water Research (RIWR) (1989) Sinai water resources study (phase II). Internal report

Rosenthal E, Zilberbrand M, Livshitz Y (2007) The hydrochemical evolution of brackish groundwater in central and northern Sinai (Egypt) and in the western Negev (Israel). J Hydrol 337:294-314

Said R (1962) The geology of Egypt. Elsevier, Amsterdam

Said R (1971) Explanatory notes to accompany the geological map of Egypt. Geol Surv Egypt (special paper 56, Cairo)

Shabana AR (1998) Geology of water resources in some catchment areas draining in the Gulf of Aqaba, Sinai-Egypt. Dissertation, Ain Shams University, Egypt

Shalaby AI (1997) Geomorphology and hydrogeology of Wadi Watir basin, SE Sinai, Egypt. Thesis, Mansoura University, Egypt

Shiftan Z (1961) New data on the artesian aquifers of the southern Dead Sea Basin. Bull Res Counc Isr 10G:267-291

Sultan M, Metwally S, Milewski A, Becker D, Ahmed M, Sauck W, Soliman F, Sturchio N, Yan E, Rashed M, Wagdy A, Becker R, Welton B (2011) Modern recharge to fossil aquifers: geochemical, geophysical, and modeling constraints. J Hydrol 403:14-24

Van der Kemp WJM, Appelo CAJ, Walraevens K (2000) Inverse chemical modeling and radioactive dating of paleogroundwaters: the tertiary Ledo-Paniselian aquifer in Flanders, Belgium. Water Resour Res 36:1277-1287

Wigely TML, Muller AB (1981) Fractionation corrections in radiocarbon dating. Radiocarb 23:173-190

Yehia MM (1998) Potentiality of the lower Cretaceous aquifer system at southeastern Sinai. Sci J (Menoufiya University, vol 12), Egypt 